\title{
Pengaruh Suplementasi Vitamin E Terhadap Kadar Prostaglandin (PGF2 $\alpha$ ) dan Intensitas Nyeri Haid (Dysmenorrhea) Primer Pada Remaja Putri
}

\author{
Iin Octaviana Hutagaol ${ }^{1}$, Sharvianty Arifuddin ${ }^{2}$, Saidah Syamsudin ${ }^{3}$ \\ 1.Bagian Kebidanan STIKes Widya Nusantara Palu,Jl.Untad 1, Palu,90231,Indonesia \\ ${ }^{2}$ Bagian Obstetri dan ginekologi, Fakultas Kedokteran Unhas,, Jl.Faisal, Makassar,90224, Indonesia \\ ${ }^{3}$ Saidah Syamsuddin, Perumahan dosen Unhas, Makassar dan 90224, Indonesia
}

\begin{tabular}{l}
\hline ARTICLE INFORMATION \\
\hline Article Trace \\
Submission: Mei 21, 2018 \\
Final Revision: July 13, 2018 \\
Available online: October 20, 2018 \\
\hline
\end{tabular}

Key Word:

Vitamin E, painful menstruation, PGF2 $\alpha$

Contact:

octavianihutagoal@gmail.com

\begin{abstract}
A B S T R A K
Nyeri haid (dysmenorrhoe) primer disebabkan oleh endometrium dalam fase sekresi memproduksi prostaglandin F2 alfa berlebih. Penelitian ini bertujuan untuk mengetahui pengaruh suplementasi vitamin $\mathrm{E}$ terhadap kadar prostaglandin (PGF2 $\alpha$ ) dan intensitas nyeri haid. Jenis penelitian ini adalah quasi eksperimen dengan pre-post control group design. Hasil Penelitian menunjukkan rerata kadar PGF2 $\alpha$ pada kelompok intervensi yang diberikan vitamin $\mathrm{E}$ lebih rendah daripada kelompok kontrol yang diberikan plasebo. Median intensitas nyeri pada kelompok intervensi yang diberikan vitamin $\mathrm{E}$ lebih rendah daripada kelompok kontrol yang diberikan plasebo. Ada Pengaruh suplementasi vitamin E terhadap kadar PGF2 $\alpha$ dan intensitas nyeri (dysmenorrhoe). Berdasarkan Paired T-test, kadar PGF $2 \alpha$ kelompok intervensi $(p=0,000)$ dan kelompok kontrol $(\mathrm{p}=0,158)$ dengan $\alpha=0,05$. Berdasarkan Uji Wilcoxon Sign Test intensitas nyeri haid kelompok intervensi $(\mathrm{p}=0,000)$ dan kelompok kontrol $(\mathrm{p}=0,480)$.
\end{abstract}

\begin{abstract}
A B S T R A C T
Painful menstruation (dysmenorrhoe) caused by a primary phase endometrium secretion producing excessive prostaglandin F2 alpha. The research aimed at investigating the effect of vitamin $\mathrm{E}$ supplementation on the prostaglandin content (PGF2 $\alpha$ ) and the primary (dysmenorrhea )intensity. This was a quasi experiment reseacrh with the pre-post test control group design The research result indicates that the average PGF2 $\alpha$ content in the intervention group who is given the vitamin $\mathrm{E}$ is lower than control group who is given the vitamin $\mathrm{E}$ is lower than the control group who is given the placebo. The pain intensity median in the intervention group who is given the vitamin $\mathrm{E}$ is lower than the control group who is given the placebo. There is the effect of the vitamin E supplementation on the PGF2a and the pain intesity (dysmenorrhoe). Based on the paired T- test, the PGF2aof the intervention group is $(p=0.000)$ and the cotrol group is $(p=0,0.158)$ with $a=0.05$. Based on Wilcoxon sign test, the menstrual pain intensity of the intervention group is $(p=0.000)$ and the control group is $(p=0.480)$.
\end{abstract}




\section{PENDAHULUAN}

Dismenore merupakan salah satu gangguan haid yang paling sering muncul pada remaja puteri dan wanita usia muda. Hal ini dapat mempengaruhi kualitas hidup remaja. Dismenore primer adalah kondisi yang umumnya menimbulkan rasa nyeri yang disertai dengan gejala lainnya. Hal ini terjadi setiap bulan pada masa reproduksi, dan berhubungan dengan siklus ovulasi normal dan tanpa disertai kelainan ginekologis. Dismenore merupakan penyebab utama ketidakhadiran remaja puteri disekolah dan hal ini membatasi aktivitas fisik mereka. Dismenore dimulai beberapa jam sebelum atau sesaat dimulainya menstruasi dan berlangsung selama 2-3 hari.

Prevalensi dismenore primer, dengan tidak adanya kelainan patologi berkisar 43-90 di antara berbagai populasi remaja puteri dan wanita usia muda. Poureslami melaporkan angka kejadian dismenore sekitar $70,5 \%$ pada kalangan remaja perempuan di Iran. Beberapa penelitian lainnya di Iran telah menunjukkan bahwa sekitar 71-89,8 dari semua wanita menstruasi mengalami beberapa ketidaknyamanan selama menstruasi.

Dismenore primer terjadi pada wanita dari segala usia subur dimulai dari usia remaja, dengan estimasi prevalensi $40-50 \%$, dismenore primer umumnya muncul pada remaja puteri kira-kira 6 sampai 12 bulan setelah menarche, dan ketika siklus ovulasi teratur ditetapkan dengan kejadian dismenore primer yang terjadi pada wanita dengan kisaran umur 14-25 tahun.

Penelitian yang dilakukan di SMPN 2 Kartasura Provinsi Jawa Tengah dari 141 putri, didapatkan sebanyak $98 \quad(69,50 \%)$ siswi mengalami dismenore, dengan tingkat nyeri ringan 61 siswi $(62,2 \%)$, sedang 30 siswi $(30,6 \%)$, dan berat 7 $(7,1 \%)$ siswi.

Penelitian yang dilakukan di Makassar dari 997 remaja puteri yang menjadi responden ada $93,8 \%$ diantaranya mengalami dismenore primer. Pada usia 13-15 tahun merupakan usia terbanyak yang mengeluhkan dismenore sebanyak $53,9 \%$ kasus. Hal ini menunjukkan tingginya prevalensi kejadian dismenorhoe primer pada remaja.

Sebagai alternatif pengganti terapi yang lebih aman dibandingkan terapi menggunakan Nonsteroid Anti Inflammatory Drugs (NSAID) seperti , terapi suplementasi, terapi herbal, terapi akupuntur, dan aroma terapi. Diantara berbagai jenis terapi tersebut, terapi suplementasi merupakan terapi yang menarik untuk diteliti, diantaranya berupa pemberian vitamin E, B1, B6, omega 3 maupun golongan mikronutrient seperti magnesium, serta zink untuk mengatasi nyeri haid.

Vitamin E dapat mengurangi nyeri haid, melalui hambatan biosintesis prostaglandin dimana vitamin $\mathrm{E}$ akan menekan aktivitas enzim fosfolipase dan siklooksiginase sehingga akan menghambat produksi prostaglandin. Sebaliknya vitamin $E$ juga meningkatkan produksi prostasiklin yang berfungsi sebagai vasodilator yang bisa merelaksasi otot polos uterus.

Tujuan penelitian ini adalah diketahuinya pengaruh suplementasi vitamin E terhadap kadar prostaglandin (PGF2 $\alpha$ ) dan intensitas nyeri haid (dysmenorrhoe) pada remaja puteri di Pondok Pesantren Darul Arqam dan Pondok Pesantren Darul Aman Makassar. berisi tentang permasalahan penelitian, tujuan penelitian, dan rangkuman kajian teoritik yang relevan, sehingga pembaca dapat memahami dan mengevaluasi hasil dari penelitian lain yang sudah dilakukan tanpa harus membaca sendiri publikasi sebelumnya tersebut. Untuk itu, naskah yang akan dikirim harus menggunakan pustaka yang benar-benar mendukung

\section{METODE PENELITIAN}

Ini dilakukan di Pondok Pesantren Darul Arqam Muhamadiyah dan Pondok Pesantren Darul Aman Gombara Makassar. Jenis penelitian ini adalah quasi eksperimen dengan pre-post control group design, yaitu melihat pengaruh suplementasi vitamin $\mathrm{E}$ terhadap kadar prostaglandin(PGF2 $\alpha$ ) dan Intensitas Nyeri haid 
(dysmenorrhoe). Sampel dalam penelitian ini sebanyak 40 orang dengan teknik purposive sampling. Penelitian yang dilakukan dari Maret sampai Mei 2016. Pengumpulan data intensitas nyeri haid dilakukan pada saat menstruasi siklus pertama dan siklus pada bulan kedua. Selanjutnya, untuk menguji kadar prostaglandin (PGF2 $\alpha$ sampel darah dianalisis di Laboratorium Rumah Sakit Universitas Hasanuddin dengan Metode ELISA.
Pengukuran intensitas nyeri haid menggunakan Numerical Rating Scale (NRS), dan pemeriksaan kadar prostaglandin pada saat nyeri haid dengan pemeriksaan laboratorium oleh ELISA di Laboratorium Rumah Sakit Universitas Hasanuddin menggunakan sampel darah sebanyak 3 cc. Selanjutnya, data yang dikumpulkan dianalisis dengan $\mathrm{Uji} T$ berpasangan dan uji Wilcoxon

\section{HASIL DAN PEMBAHASAN}

Tabel 1. Perbedaan Kadar PGF2 $\alpha$ Sebelum Dan Sesudah Perlakuan Pada Kelompok Vitamin E dan Plasebo

\begin{tabular}{|c|c|c|c|c|c|c|c|}
\hline \multirow{2}{*}{ Variabel } & \multirow{2}{*}{$\mathbf{n}$} & \multicolumn{2}{|c|}{ Sebelum } & \multicolumn{4}{|c|}{ Sesudah } \\
\hline & & Median & Rentang & $P$ & Median & Rentang & $\mathrm{P}$ \\
\hline Vitamin E & 20 & 2 & $1-3$ & & 1 & $1-2$ & \\
\hline Plasebo & 20 & 2 & $1-3$ & 0,451 & 2 & $1-3$ & 0,000 \\
\hline
\end{tabular}

Tabel 2. Median Intensitas Nyeri Haid Sebelum Dan Sesudah Perlakuan Pada Kelompok Vitamin E dan Plaseb

\begin{tabular}{cccccccc}
\hline \multirow{2}{*}{ Variabel } & \multirow{2}{*}{$\mathbf{n}$} & \multicolumn{2}{c}{ Sebelum } & \multicolumn{2}{c}{ Sesudah } & \multirow{2}{*}{ Range } & p \\
\cline { 3 - 6 } & & Mean & SD & Mean & SD & & \\
\hline Vitamin E & 20 & 1231,10 & 150,08 & 819,75 & 132,72 & 411,35 & 0,000 \\
Plasebo & 20 & 1199,80 & 377,47 & 1136,50 & 421,80 & 63,30 & 0,158 \\
\hline
\end{tabular}

Tabel 3. Perbedaan Intensitas Nyeri Haid Sesudah Perlakuan Pada Kelompok Vitamin E dan Plasebo

\begin{tabular}{cccccc}
\hline \multirow{2}{*}{ Variabel } & $\mathbf{n}$ & \multicolumn{3}{c}{ Intensitas Nyeri Sebelum- } & \multirow{2}{*}{ Sesudah } \\
\cline { 3 - 5 } & & $\begin{array}{c}\text { Men } \\
\text { urun }\end{array}$ & Tetap & Meningkat & \\
\hline Vitamin E & 20 & 18 & 2 & 0 & 0,000 \\
Plasebo & 20 & 2 & 15 & $\mathbf{3}$ & 0,480 \\
\hline
\end{tabular}

Pada tabel 1 kadar prostaglandin pada kelompok intervensi (vitamin e) sebelum diberi perlakuan rata-rata kadar prostaglandin 1231,10 $\mathrm{pg} / \mathrm{ml} \pm 150,08$, dan rata-rata kadar prostaglandin sesudah diberikan vitamin e adalah 819,75 $\mathrm{pg} / \mathrm{ml} \pm 132,72$. Analisis kemaknaan dengan paired t-test menunjukkan bahwa nilai $\mathrm{p}=0,000$ $(p<0,05)$ dengan selisih $411,35 \mathrm{pg} / \mathrm{ml}$. Hal ini berarti bahwa rata-rata penurunan kadar prostaglandin sebelum dan sesudah perlakuan menunjukkan bahwa ada perbedaan antara sebelum dan sesudah diberikan vitamin e pada kelompok intervensi, sementara pada kelompok kontrol (plasebo) sebelum diberikan perlakuan rata-rata kadar prostaglandin 1199,80 $\mathrm{pg} / \mathrm{ml} \pm 377,47$, dan rata-rata kadar prostaglandin sesudah diberikan plasebo adalah $1136,50 \pm 421,80$. Analisis kemaknaan dengan paired t-test menunjukkan bahwa nilai $\mathrm{p}=0,158$ $(\mathrm{p}>0,05)$ dengan selisih $63,30 \mathrm{pg} / \mathrm{ml}$ artinya tidak ada perbedaan bermakna sebelum dan sesudah diberikan plasebo.

Pada tabel 2 dan tabel 3 dari 20 responden pada kelompok vitamin e didapatkan 
penurunan intensitas nyeri haid 18 responden tingkat nyerinya turun, 2 responden nyerinya tetap setelah diberikan vitamin e dengan median 2 dan rentang 1-2. Hasil uji statistik didapatkan nilai $\mathrm{p}=0,000 \quad(\mathrm{p}<0,05)$. Hal ini berarti ada perbedaan tingkat nyeri antara sebelum dan sesudah diberikan vitamin e, sementara dari 20 responden pada kelompok plasebo didapatkan 2 responden mengalami penurunan intensitas nyeri, 15 responden intensitas nyeri tetap, dan 3 responden mengalami kenaikan nyeri haid dengan median 2 dan rentang 1-3. Hasil uji statistik menggunakan wilcoxon sign test menghasilkan nilai $\mathrm{p}=0,480 \quad(\mathrm{p}>0,05)$ artinya tidak ada perbedaan tingkat nyeri sebelum dan sesudah diberikan plasebo.

Hasil penellitian didapatkan ada perbedaan bermakna antara kadar prostaglandin sebelum dan sesudah pemberian vitamin e dibandingkan dengan kadar prostaglandin sebelum dan sesudah pemberian plasebo dengan dengan jumlah sampel masing-masing 20 orang untuk tiap kelompoknya. Penurunan kadar prostaglandin sesudah perlakuan pada kelompok yang diberikan intervensi sesuai dengan penelitian di iran yang berjudul evaluation of the effect of vitamin e on pelvic pain reduction in women suffering from primary dysmenorrhea, penurunan prostaglandin disebabkan karena fungsi dari vitamin e yang diberikan pada kelompok perlakuan. Vitamin e berfungsi untuk mencegah peroksidasi fosfolipid, pelepasan asam arakidonat yang mengakibatkan penurunan prostaglandin. Vitamin e merupakan suatu antioksidan yang dapat menghambat pelepasan asam arakidonat dengan mekanismenya dalam menginhibisi protein kinase c, yang dapat mempengaruhi aktifitas dari enzim fosfolipase a2, sehingga dengan adanya penghambatan terhadap sintesis asam arakidonat akan mengurangi produksi prostaglandin sebelum menstruasi yang merangsang terjadinya nyeri pada saat menstruasi (dysmenorrhoe).

Sebuah penelitian yang dilakukan di virginia yang berjudul clinical efficacy and differential inhibition of menstrual fluid prostaglandin f2ain a randomized, double-blind, crossover treatment with plasebo, acetaminophen, and ibuprofen inprimary dysmenorrhea, dengan mengukur kadar pgf2 $\alpha$ pada darah menstruasi yang terdapat dalam tampon, didapatkan bahwa kadar pgf2 $\alpha$ dua kali lebih tinggi pada wanita yang mengalami nyeri haid dibandingkan dengan yang tidak mengalami nyeri haid dengan nilai $\mathrm{p}=0,002(\mathrm{p}<0,005)$.

Hal ini sejalan dengan penelitian di iran dengan judul a comparison of the effects of vitamin e and vitamin b1 on the severity and duration of pain in primary dysmenorrhoe meneliti efek dari vitamin e pada remaja usia 16 sampai 18 tahun yang menderita dismenore primer dengan hasil penelitian $p=0,001 \quad(p<0,05) \quad$ yang artinya vitamin e ditemukan efektif dalam mengurangi tingkat nyeri haid dan kadar prostaglandin pada saat menstruasi.

Hasil penelitian didapatkan setelah diberikan perlakuan pada kelompok intervensi ada 18 responden diantaranya mengalami penurunan nyeri dan 2 responden berada pada nyeri yang sama antara sebelum dan sesudah pemberian vitamin e dengan nilai $\mathrm{p}=0,000$ yang berarti ada perbedaan bermakna setelah pemberian vitamin e. Sedangkan pada kelompok kontrol yang diberikan plasebo ada 2 responden diantaranya mengalami penurunan nyeri, 15 responden mengalami nyeri yang sama dan 3 responden nyeri haid meningkat setelah perlakuan dengan nilai $\mathrm{p}=0,480$ yang berarti tidak ada perbedaan bermakna setelah pemberian plasebo. Penelitian ini sejalan dengan penelitian yang berjudul evaluation of the effect of vitamin e on pelvic pain reduction in women suffering from primary dysmenorrheal di iran dengan pemberian vitamin e 400 iu selama 2 hari dimulai dari hari kedua sebelum hari haid pertama mempunyai perbedaan bermakna dibandingkan dengan plasebo dalam mengurangi nyeri haid yang diukur dengan visual analog scale (vas) dengan rata-rata nyeri sebelum perlakuan pada

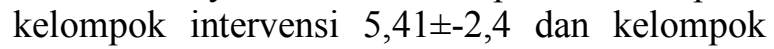

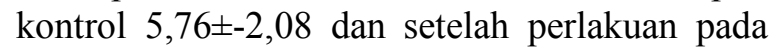
siklus haid berikutnya yakni kelompok

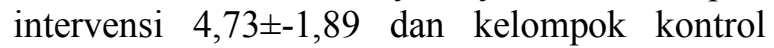

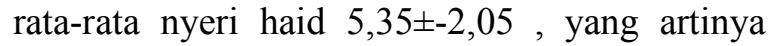
vitamin e efektif dalam penurunan tingkat nyeri haid dibandingkan dengan placebo.

Penurunan tingkatan nyeri pada kelompok intervensi yang diberikan vitamin e sejalan dengan penelitian serupa dari 278 remaja berusia 15 sampai 17 tahun yang menderita dismenore primer, peserta diberi 400 iu vitamin e pada 5 hari sebelum menstruasi. Hasil penelitian menunjukkan respon secara signifikan lebih besar dan lebih berkelanjutan pada kelompok 
perlakuan selama diberikan suplementasi vitamin e.

Korelasi antara kadar prostaglandin dengan intensitas nyeri haid sesuai dengan teori yang menyatakan kadar prostaglandin yang meningkat ditemukan di cairan endometrium perempuan dengan dismenore dan berhubungan dengan tingkat nyeri seorang wanita pada saat menstruasi. Peningkatan prostaglandin di endometrium sebanyak 3 kali lipat terjadi dari fase folikuler menuju fase luteal, dengan peningkatan lebih lanjut yang terjadi selama haid. Peningkatan prostaglandin di endometrium yang mengikuti penurunan progesterone pada akhir fase luteal menimbulkan peningkatan tonus miometrium dan kontraksi uterus yang berlebihan yang merangsang terjadinya nyeri pada saat menstruasi.

Penelitian lain menyatakan bahwa respon terhadap inhibitor prostaglandin pada pasien dengan dismenorrhoe mendukung pernyataan bahwa dismenore primer dimediasi oleh prostaglandin. Peningkatan kadar prostaglandin ditemukan dicairan endometrium wanita dengan dismenore primer dan berhubungan derajat nyeri haid.

Prostaglandin menyebabkan peningkatan aktivitas uterus dan serabut syaraf terminal ransang nyeri. Kombinasi antara peningkatan kadar prostaglandin dan peningkatan kepekaan miometrium menimbulkan tekanan intra uterus sampai $400 \mathrm{mmhg}$ dan menyebabkan kontraksi miometrium yang hebat. Atas dasar itu disimpulkan bahwa prostaglandin yang dihasilkan uterus berperan dalam menimbulkan hiperaktivitas miometrium. Kontraksi miometrium yang disebabkan oleh prostaglandin akan mengurangi aliran darah, sehingga terjadi iskemia sel-sel miomterium yang mengakibatkan timbulnya nyeri spasmodic.

Terdapat hubungan antara derajat nyeri haid dan produksi prostaglandin dan ditemukan adanya substansi dalam darah menstruasi yang menstimulasi kontraksi otot polos uterus. Substansi tersebut mengandung pgf2 $\alpha$ dimana rasio pgf $2 \alpha$ lebih tinggi dalam endometrium dan darah menstruasi wanita yang mengalami nyeri haid primer. Peningkatan $\operatorname{pgf} 2 \alpha$ meransang kontraksi uterus selama seluruh fase siklus menstruasi.

\section{KESIMPULAN}

Rerata kadar prostaglandin (PGF2 $\alpha$ ) kelompok intervensi yang diberikan vitamin $\mathrm{E}$ lebih rendah dibandingkan kelompok kontrol yang diberikan plasebo. Ada perbedaan bermakna kadar PGF2 $\alpha$ dan intensitas nyeri haid pada kelompok vitamin E, sedangkan pada kelompok plasebo tidak ada perbedaan bermakna kadar PGF2 $\alpha$ dan intensitas nyeri haid. Ada pengaruh suplementasi Vitamin E terhadap kadar prostaglandin PGF2 $\alpha$ dan intensitas nyeri haid primer pada remaja puteri.

\section{DAFTAR PUSTAKA}

Clark. et al. (2008). Prostaglandin and The Reproductive Cycle. Ohio: Glowm

Dawood MY. \& Firyal S. (2007). Clinical Efficacy And Differential Inhibition of Menstrual Fluid Prostaglandin F2ain a Randomized, Double-Blind, Crossover Treatment With Plasebo, Acetaminophen, and Ibuprofen Inprimary Dysmenorrhea, Virginia, 196(1)

Dehkordi ZR. et al. (2014). Effect Of Lavender Inhalation on Thesymptoms of Primary Dysmenorrhea and Theamount of Menstrual Bleeding: Arandomized Clinical Trial Complementary Therapies, Iran, 22: 212-219

Dito A. \& Ari W., (2011). Menstrual Pain Treatment. Yogyakarta: Andi

Gumilar. (2014). The Influence Of Health Education To Changes In Knowledge And Attitudes Girls About Mensstrual Pain. Available from: http://eprintsjournal.ums.ac.id

Harel. \& Zeev MD. (2006). Dysmenorrhea in Adolescents and Young Adults: Etiology and Management, Rhode island, 19:363-371

Ji Y. et al. (2014). Effectiveness Study of Moxibustion on Pain Relief in Primary Dysmenorrhea: Study Protocol of a Randomized Controlled Trial, Cina, 10:1155 
Kashanian et al. (2013). Evaluation of the effect of vitamin $E$ on pelvic pain reduction in women suffering from primary dysmenorrhea, Iran, 58:34-38

Nasehi M. (2013). Comparison of the effectiveness of combination of fennel extract/vitamin E with ibuprofen on the pain intensity in student with primary dysmenorrhea, Iran, 18(5).

Nayeban S. et al. (2014). A Comparison of the Effects of Vitamin E and Vitamin B1 on the Severity and Duration of Pain in Primary Dysmenorrhea . Journal of Midwiferry \& Reproductive Health, Iran, 2 (2): 143-146.
Saryono. \& Sejati W. (2009). Premenstrual Syndrome. Yogyakarta : Nuh Medika

Utami ANR., Ansar J., \& Sidik D. (2013). The factors related to menstrual pain in adolescent girls in SMAN 1 Kahu Kabupaten Bone. repository Unhas.ac.id

Woo P. \& Mc. Eneaney M J. (2010). New Strategies To Treat Primery Dysmenorhea. USA: Clinical Advisor .

Ziaei S. et al. (2005). A randomised controlled trial of vitamin $\mathrm{E}$ in the treatment of primary dysmenorrhoea, Iran, 112: 466469. 